\title{
I realized that you would conjecture...
}

An ethnocritical reading of Borges

Je compris que vous conjecturiez... Ethnocritique d'un récit de Borges

\section{Jean-Marie Privat}

Translator. Stephen Ward Butler

\section{(2) OpenEdition}

\section{Journals}

\section{Electronic version}

URL: https://journals.openedition.org/pratiques/10310

DOI: 10.4000/pratiques.10310

ISSN: 2425-2042

\section{Publisher}

Centre de recherche sur les médiations (CREM)

\section{Electronic reference}

Jean-Marie Privat, "I realized that you would conjecture...", Pratiques [Online], 181-182 | 2019, Online since 15 January 2021, connection on 03 September 2021. URL: http://journals.openedition.org/ pratiques/10310 ; DOI: https://doi.org/10.4000/pratiques.10310

This text was automatically generated on 3 September 2021.

(c) Tous droits réservés 


\section{I realized that you would conjecture...}

An ethnocritical reading of Borges

Je compris que vous conjecturiez... Ethnocritique d'un récit de Borges

Jean-Marie Privat

Translation : Stephen Ward Butler

1 Raphaël Baroni (2003, p. 155) concluded his analysis of Jorge Luis Borges's short story "Death and the Compass" ${ }^{1}, 2$ [ La muerte y la brújula in the original Spanish; the French translation, La mort et la boussole (1974), was used by the author for this analysis] by emphasising the degree to which this story allows the reader to "become aware of the many generic expectations readers have for detective stories." While we certainly understand the full value of this narratological point of view, what we would like to examine here is rather the cultural pact that this short story establishes. It is a story of a meticulously drawn city map, of a plot hatched by a murderer and the cunning plan of a logographic narrator.

\section{A detective story, or sowing confusion within the narrative}

2 Borgesian narratives feature composite and even deliberately heterogeneous cultural universes. It is as if the writer was hoping to confuse his readers - often right from the title - and disorient them by creating multiple and intersecting worlds.

\section{A disturbing familiarity}

3 First, there are the unexpected, even oxymoronic lexical formulas - "black eucalyptus", "unlucky murderer", "abhorrent whiteness", "gods of fever", "pointless cry of a bird", "the next time I kill you", etc. - and then there are the sibylline formulations that obviously play the role of cognitive provocation from the very first lines. 
Of the many problems on which Lönnrot's [the detective] reckless perspicacity was exercised, none was so strange - so rigorously strange, one might say - as the periodic series of bloody deeds that culminated at the Villa Triste-Le-Roy, amid the perpetual fragrance of the eucalyptus (Borges, 1974, p. 149).

4 detective himself: "He had virtually solved the problem; the mere circumstances, the reality (names, arrests, faces, the paperwork of trial and imprisonment), held very little interest for him now. He wanted to go for a walk, he wanted a respite from the three months of sedentary investigation" (ibid.). "I promise you the labyrinth that consists of a single straight line that is invisible [...] (ibid., p. 163).

7 Oscillating between the effect of reality and unreality, the world of the Borgesian narrative is thus at once gripping and elusive, obvious and hidden, near and far. It disrupts ordinary chronological and worldly landmarks - "It was one of those deserted evenings that have the look of dawn" (ibid., p. 157) - or inserts a dreamlike and nightmarish bestiary: "a silvery horse lapping at the rank water of a puddle" (ibid., p. 158). This uneasiness about the nature of people and situations, this uncertainty about motives and even behaviours are as if refracted or crystallised in a shaky onomastic description - "I am Gryphius-Ginzberg-Ginsburg [...], Red Scharlach [...], Scharlach the Dandy" (ibid. p. 161 and 149). This becomes all the more apparent in the enigmatic place names, such as the Villa Triste-Le-Roy, with its "perpetual fragrance of the eucalyptus" (ibid., p. 149) and its "rectangular belvedere" (ibid., p. 158).

It continues through to the ruthless planning of a tragedy announced as a fatal game "Kill me at D, as you are about to kill me at Triste-Le-Roy" (ibid., p. 163) - it is thus death that is on the prowl ${ }^{3}$ and it is undoubtedly this generic and anthropological mechanism that ties together the strange and the familiar, the calmness and anxiety of the story and its reader: "What seems strangely disturbing to many people is that which is associated with death [...]" (Freud, 2001, p. 99). This "primitive anguish in the face of death" (ibid., p. 103) is what creates the twists and turns of fiction, sets out its contours and loops, establishes the resonance between fairy tale and nightmare, ${ }^{4}$ between solitude and silence, between beauty and mystery, between eternity and finite existence: "A final alleyway lined with pink-colored walls that somehow seemed to reflect the rambunctious setting of the sun" (Borges, 1974, p. 153). "A bedchamber stopped him; there, a single flower in a porcelain vase; at the first brush of his fingertips, the ancient petals crumbled" (ibid., p. 159). "A round yellow moon defined two leaf-clogged fountains in the dreary garden (ibid., p. 158). "The moonlight of the 
evening shone through the lozenges of the windows [...]. He was stopped by an astonished, dizzying recollection" (ibid., p. 159).

\section{An honour-bound society}

9 But in fact, the words could trick us if Borges' writing were not also read as a kind of false enigma where the narrator plays with us, telling us from the beginning through botanical language that the rhetoric of the text is similar to the long-hidden beauty of the eucalyptus flower ${ }^{5}$ and through the language of a factual and impassive chronicle that a radical, if not deadly, cultural belligerence opposes the two main protagonists: "That criminal (like so many others) had sworn upon his honor to kill Lönnrot, but Lönnrot never allowed himself to be intimidated" (ibid., p. 149).

Indeed, what does a society's philosophy of honour share with an individual's perception of professional courage? Nothing, except a possible dangerous misunderstanding.

11 However, honour is not an empty word in societies ruled by an honour code. ${ }^{6}$ This law of honour becomes a theme within the text itself. Scharlach, the gang leader, had planned the theft of the magnificent sapphires from a prominent religious leader, the Tetrarch of Galilee, who was mistaken for a learned rabbi, Professor Yarmolinsky. Azevedo was put in charge of carrying out the plan but he got drunk with the money he received in advance and got lost in the hotel where the Tetrarch and the Professor were staying. When he broke into the room at night by mistake, Yarmolinsky was still awake. To stop him from crying out, Azevedo stabbed him in the chest: "The movement was almost reflexive; a half century of violence had taught him that the easiest and safest way is simply to kill..." (ibid., p. 150).

12 He made a mistake, and he quickly paid for this pointless murder with his own life; it was the price of his irresponsible betrayal of the collective cause. Scharlach explains it to Lönnrot: "Daniel Azevedo was the necessary victim. He deserved to die; he was a man that acted on impulse and he was a traitor - if he were captured, he could destroy my plan. One of my men stabbed him" (ibid., p. 161).

13 Azevedo - "a man of some reputation in the old slums of the Northside" and "the last representative of a generation of outlaws who used a knife but not a revolver" (ibid., p. 153) - was in fact discovered by the detectives and gendarmes, with his face looking "as though it were wearing a mask of blood", an explicit signature of the bloody vengeance that traditionally humiliates the corpse of the condemned or banished. ${ }^{7}$ The narrator acknowledges this: "the singular manner of his death seemed fitting" (ibid.).

Thus, one can break the honour of one's word, and more generally the codes and laws of honour, like Azevedo, or save/recover one's honour, if honour has been violated. It is a matter of man and honour, a matter of being a man of honour:

Three years ago [...] you [Lönnrot] arrested my brother and saw that he was sent to prison [...] the rectangular prison where my brother lay dying [...]. My men rescued me from the shoot-out in a coupe, but not before I'd received a policeman's bullet in my gut [...]. I swore by the god that sees with two faces, and by all the gods of fever and of mirrors, to weave a labyrinth around the man who had imprisoned my brother [...]. He stepped back a few steps. Then, very carefully, he fired [at Lönnrot] (ibid., p. 160 and 163). demands not pure or blind revenge in the archaic or impassioned sense of the word, 
but inescapable hatred and flawless execution: the blood crime ${ }^{9}$ is then a crime of honour. This was the price for symbolic reparation and Borgesian narrative:

"Two fierce, stocky men leaped upon him [Lönnrot] and disarmed him; another, quite tall, greeted him gravely: 'You are so kind. You have saved us a night and a day.' It was Red Scharlach [...]. But then he spoke, and Lönnrot heard in his voice a tired triumphance [...]. Lönnrot avoided Scharlach's eyes (ibid., p. 159 and 162).

\section{The (bad) death} who have a local reputation to defend. This is the case, for example, when the narrator reports, reflecting the viewpoint of the small community where everyone knew each other, that Red Scharlach, "the most famous gunman of the Southside [...], swore that in his territory no crime such as that had ever taken place, and he accused Police Commissioner Franz Treviranus of criminal negligence" (ibid., p. 156). But if this feeling of honour and dishonour here becomes a fatal matter of honour, it is because it is also linked to the precise conditions of Scharlach's brother's death. It is the custom as a whole that is at stake and a raw wound (honour, sworn oath, revenge, blood vengeance, brotherhood, virility, ritual duty etc.). page in a story - is indeed conveyed as an end without honour: he suffered a premature and violent death, a solitary and sudden death, without rite or humanity - in short, a bad death. ${ }^{10}$ This insult to the brother's dying body and death is a personal affront and symbolic humiliation that is all the more striking within the culture of the text since the alter ego of the two brothers has himself had the nightmarish experience of being the wounded man near death:

[...] a policeman's bullet in my gut. Nine days and nine nights I lay between life and death in this desolate symmetrical villa, consumed by fever [...]. I came to abominate my own body. [...] I sensed that the world was a labyrinth, impossible to escape [...], the rectangular prison where my brother lay dying, and which was also the Villa Triste-Le-Roy [...]. During those nights, I swore by the god that sees with two faces [...] to weave a labyrinth around the man who had imprisoned my brother (ibid., p. 160).

In fact, in this story, no one dies a natural death: the rabbi is murdered by mistake, ${ }^{11}$ the criminal is punished in the old fashioned way on the orders of the gang leader, ${ }^{12}$ the detective himself is summarily shot dead.

\section{The adequacy of the Logos}

19 It thus appears that the Borgesian version of the genre-related pathos of the classic detective story (and its parody or pastiche) does not exclude - quite the contrary - the cultural dimension of the oppositions that structure the relationships to life and death of the criminal underworld and the institutions handling the investigation. And as we shall see, the agents of these institutions (detectives, commissioners and other gendarmes and even journalists) are not driven by the same cultural and professional logic. 


\section{The power of written culture} perception of the world is part of a true scriptural consciousness: for example, the " $R$ floor", the "numbered divisibility of a prison", the "rectangular water" of a pier, or a "rectangular prison". Better still, it is in the narrative dynamic of the story that the scriptural aspects are viewed as sacred or taboo:

The Tetragrammaton, the Name of God, YHVH, consists of four letters [...], the ineffable Name of God [...] (ibid., p. 162 and 152).

I read [...]. I learned that the reverent fear of speaking the Name of God had been the origin of the doctrine that that Name is omnipotent and occult. I learned that some Hasidim, in the quest for that secret Name, had gone so far as to commit human sacrifice... (ibid., p. 161).

Finally, written culture is part of the narrator's own world, not only in the strange and ambiguous lexical choices - "Lönnrot made his way forward through the eucalyptus trees, treading upon confused generations of stiff red leaves" (ibid., p. 158) - but also and especially in a series of factual clarifications that connect writing and death, until the final outcome:

Lönnrot [...] Suddenly turned bibliophile or Hebraist, he ordered one of the officers to wrap up the dead man's books and he took them to his apartment [...], he set about studying them (ibid., p. 152). 
Daniel Azevedo was the necessary victim. He deserved to die; he was a man that acted on impulse and he was a traitor [...]. One of my men stabbed him; in order to link his body to the first one, I wrote The second letter [...] across the rhombuses of the paint factory (ibid., p. 161). story that the finale is an attempt to create a criminal scenario in geometric terms ${ }^{14}$ and the graphic rigour of certainty can be read even in the schematic materiality of the explanation:

There are three lines too many in your labyrinth [...]. I know of a Greek labyrinth that is but one straight line [...]. One crime at $\mathrm{A}$, a second crime at $\mathrm{B}$, eight kilometers from $\mathrm{A}$, then a third crime at $\mathrm{C}$, four kilometers from $\mathrm{A}$ and $\mathrm{B}$ and halfway between them. Then wait for me at D, two kilometers from A and C, once again halfway between them. Kill me at D [...] (Borges, 1974, p. 163).

\section{Commissioner Treviranus or positive factual science}

The commissioner has only one goal in mind: establish the facts and restore public order as his job requires. His hypothetico-deductive reasoning means he sees the world as it is through a concrete and objective lens, and he gladly leaves the letters and maps - "this sort of claptrap" (ibid., p. 156) - to Lönnrot: "Treviranus received an impressivelooking sealed envelope [...]. Red ink on the map demonstrated its [the triangle's] regularity. Treviranus read over that argument-by-geometry resignedly [...]" (ibid.).

This clear rationality has the assurance of traditional common sense, or even professional doxa:

'No need to go off on wild-goose chases here,' Treviranus was saying, as he brandished an imperious cigar. 'We all know that the Tetrarch of Galilee owns the finest sapphires in the world. Somebody intending to steal the sapphires broke in here by mistake. Yarmolinsky woke up, the burglar had to kill him (ibid., p. 134135).

The pragmatic commissioner and the book-obsessed detective are immediately at odds on how to get to the truth, in an argument that is not without "humour": "[...] Lönnrot replied. "What we have here is a dead rabbi; I would prefer a purely rabbinical explanation, not the imaginary bunglings of an imaginary burglar"' (ibid., p.151). "Treviranus' humor darkened. 'I'm not interested in "rabbinical explanations," as you call them; what I'm interested in is catching the blackguard that stabbed this unknown man"' (ibid.).

Is Lönnrot fascinated by the rabbi's "complete works", arranged on a bureau in the room? The commissioner looks at them for a moment, first "with fear, almost with revulsion. Then he laughed. 'I'm a poor Christian fellow [...]. You can take those things home with you, if you want them; I can't be wasting my time on Jewish superstitions" (ibid.).

31 Treviranus' theory has nothing to do with historic or theological references; it is a prosaic scenario involving classic motives - here, money - to shed light on his case. He's not looking for anything. He's investigating.

This practical logic (a crime, a motive, a theory, fieldwork, witness canvassing etc.) allows him to quickly discover, for example, that a certain Gryphius had called him:

Treviranus drove immediately to Liverpool House. The owner had the following to say: Eight days earlier [...] Then he examined Gryphius-Ginsburg's little room. On the floor, there was a brusque star, in blood [...], on a bureau, a book in Latin [...] 
with several handwritten notes. Treviranus looked at it indignantly, and sent for

Lönnrot [...]. (ibid., p. 154.)

We can see here that even if both are able to keep a cool head - just a couple of hours after the viciously stabbed man was found, the two men "serenely discussed the problem" (ibid., p. 150) in the same room where the body was lying - their respective methods and ethos are completely different: "[...] Lönnrot did not take his hat off before plunging into the book, while the commissioner interrogated the contradictory witnesses to the possible kidnapping" (ibid., p. 155).

The commissioner has a certain flair - he quickly suspects that the third "crime" is a "sham, a simulacrum" (ibid., p. 161) - while the detective insisted on reading an intentionally underlined passage from Philologus' thirty-third dissertation "in a grave voice" (ibid., p. 139). Treviranus says ironically, "And is that the most valuable piece of information you've picked up tonight, then?" (ibid., p. 155-156).

\section{Lönnrot, "a reasoning machine" or graphic unreason}

35 Lönnrot is indeed something of a philologist and "a reasoning machine" (ibid., p. 149). But his aim is less to cognitively determine the outlines of a criminal case than to understand the "secret shape" (ibid.) of a cultural process at work. In short, he is the man of Logos and literacy. He is not the man of causal logic, of factual observation, of empirical evidence, of positive contextual reasoning (noting, observing, questioning, describing, comparing, examining). Nor does he share the commissioner's sceptical scientism (religion, beliefs and philosophical speculation seem to the commissioner to be as futile as they were to Monsieur Homais, the scientistic and positivistic apothecary of Gustave Flaubert's novel Madame Bovary [1857]). In fact, Lönnrot looks more for signs than for clues. And so, he begins his investigation with books before all else. Thus, he is "indifferent to the police investigation" and begins studying the "dead man's books" that he had had taken to his apartment (ibid., p. 152). Lönnrot puts his imagination to work in the imaginary world of writing. He does not feel it is a waste of time to delve into "the history of Jewish superstitions" (ibid., p. 151). Quite the contrary - he rather enjoys his "erudite research" in the secrecy of his office: "One book, an octavo volume, revealed to him the teachings of Israel Baal Shem Tov [...]; another, the virtues and terrors of the Tetragrammaton [...]; yet another, the notion that God has a secret name [...]" (ibid., p. 152).

When a writer from an important newspaper interrupts him from his scholarly reading to talk about the murder, Lönnrot "preferred to talk about the many names of God" (ibid.). The misunderstanding and incomprehension is clear: "The journalist [from the Yiddische Zeitung] filled three columns with the story that the famed detective Erik Lönnrot had taken up the study of the names of God in order to discover the name of the murderer. Lönnrot, accustomed to journalists' simplifications, did not take offense" (ibid.).

37 He attentively "studied" the items the commissioner gave him (ibid., p. 156). He even thought "he was on the brink of solving the riddle" (ibid.), with a drawing-compass and navigational compass - intellectual technologies - to help him (Goody, 2006, p. 7-30; 1979).

But this apparent rationality is unreason that lasts "a hundred days" and distracts him from the investigation (Borges, 1974, p. 157). It leads him to no longer be interested in 
"the mere circumstances, the reality (names, arrests, faces, the paperwork of trial and imprisonment)" [...] (ibid.). In short, he becomes removed from "reality", ${ }^{15}$ to such a point that he finally declares that after "three months of sedentary investigation" (ibid.) all he wanted was a break from "dusty" Greek and Latin words. What better way to say that Lönnrot is an intemperate scriptophile so close to graphic unreason and that he will throw himself into the lion's den:

I [Scharlach] learned [...] that you were trying to find the key to Yarmolinsky's death among Yarmolinsky's writings. [...] I realized that you would conjecture that the Hasidim had sacrificed the rabbi; I set about justifying that conjecture [...] I had repeatedly dropped clues so that you, the reasoning Erik Lönnrot, would realize [...]. It was I who underlined that passage in Leusden's book [...]. I knew you would add the missing point (ibid., p. 161-162 ${ }^{16}$ ).

Lönnrot the exegete is trapped by his own graphic speculations, and he can only agree tragically:

I know of a Greek labyrinth that is but one straight line. So many philosophers have been lost upon that line that a mere detective might be pardoned if he became lost as well. [...] Scharlach, I suggest you fake (or commit) one crime at A, a second crime at B [...]. Kill me at D, as you are about to kill me at Triste-le-Roy [...]. Then, very carefully, he [Scharlach] fired (ibid., p. 162-163).

Thus, like Edgar Allen Poe's August Dupin, to whom the text compares him from the outset, ${ }^{17}$ hidden away in his reading room, Lönnrot is very similar to this "armchair hermeneutic" discussed by Tzvetan Todorov (1971, p. 55-65), an armchair investigator who tends to stumble over what is and to partly explain what is not. ${ }^{18}$

While the positivist commissioner and grammatologist detective diverge in their professional practices, and while their personal worlds do not save them from unpleasant surprises, it is the man of letters - in the fullest sense of the word - who will not survive the machinations of the criminal who "had sworn upon his honor to kill Lönnrot" (Borges, 1974, p. 149).

\section{The cunning intelligence of metis}

Lönnrot considered himself to be a "reasoning machine" - the man of line and indentation - and he felt that "the mystery seemed so crystal clear" (Borges, 1974, p. 149 and 157). And even if the commissioner had guessed correctly - this carnival "prank" (ibid., 154) was "a mere sham, a simulacrum" (ibid., 161) - Red Scharlach was skilfully playing with them. Indeed, neither the institutional logic of the investigation (in the field) nor the intellectual logic of the quest (on paper) can outwit the honourbound criminal's cunning intelligence: "I realized that you would conjecture [...]; I set about justifying that conjecture" (ibid.).

This ethos of the criminal, his symbolic universe and his cunning praxis no longer require exploring the modus operandi of police investigations but rather the anthropological logic that underpins Scharlach's vindictive behaviour. Playing the enemy's game to thwart him ("getting lost" in conjecture...) is metis itself:

In the first place, the intelligent ability referred to as metis comes into play on widely varying levels but in all of them the emphasis is always laid on practical effectiveness, on the pursuit of success in a particular sphere of activity: it may involve multiple skills useful in life, the mastery of the artisan in his craft, magic tricks, the use of philtres and herbs, the cunning stratagems of war, frauds, deceits, 
resourcefulness of every kind (Detienne \& Vernant, $1974^{19}$, p. 10; see also Hartog, $\left.1977^{20}\right)$.

Thus, the man of metis must combine "an agile mind, a good eye and immediate understanding of any new situation" (ibid., p. 302). ${ }^{21}$ If need be, he will play using stratagem and trickery on all the boards to accomplish his goal. Here, the aim is to slyly lure ${ }^{22}$ the other into a mortal ambush:

The first term of the series was given me quite by chance [...]. Ten days later I learned from the Yiddische Zeitung that you were trying to find the key to Yarmolinsky's writings." I learned [...], I learned. I realized [...]. I set about justifying that conjecture (Borges, 1974, p. 160-161).

Scharlach notes that Lönnrot favours a scholarly and bookish relationship to the world. He even quickly understands that his enemy's point of honour is scholastic reason ${ }^{23}$ : that reflexive and speculative time detached from urgency and action, a time that is willingly turned towards the past and which differs from the present interactions of the social game and its stakes, a learned distance and literary detour that is realised par excellence in the scholar's studium and otium. This distant and distinctive relationship to the world of common sense somehow gives shape to a kind of scholastic unreason, an elitist intellectualism that gladly draws from logic to understand the logic of things. Yet this hubris of pure thought, which is the true aristocratic point of honour of the thinker, is literally based on "an abuse of language" (Bourdieu 1997: 36-39) and almost by academic definition - on a type of fetishism of written language (books, monographs, dead languages, nomenclatures, dissertations, scholarly research, commentaries, annotations, speculation, etc.).

This is why Scharlach does not resort to blunt force but rather to trickery to set his traps (opting for disguise ${ }^{24}$ and ambush). He especially knows how to turn Lönnrot's strength against him (including by divulging the ruse that has put Lönnrot at the criminal's mercy):

[...] That sentence revealed that this was a series of three crimes. At least that was how the man in the street interpreted it - but I had repeatedly dropped clues so that you, the reasoning Erik Lönnrot, would realize that there were actually four [...]. It was I who underlined that passage [...] the passage gives one to understand that [...] (Borges, 1974, p. 162).

It is this duplicitous connivance with reality in situ that tightens Scharlach's final grip on his enemy, and all the more so when combined with a tactical intelligence that accurately and precisely anticipates the other's actions and reactions, to the point of making him look foolish and hunting him down like an animal: "I knew you would add the missing point [...], the point that fixes the place where a precise death awaits you. I [...] planned all this [...]. Lönnrot avoided Scharlach's eyes [...]. When you hunt me down in another avatar of our lives [...]" (ibid.).

We can see the extent to which Scharlach/Gryphius ${ }^{25}$ manipulates the written culture (sentence, clue, underlining, passage, point) that is so important to Lönnrot to mislead the reader ("realize", "know/understand" and "gives one to understand") and alert the reader to the connection that the text clearly establishes with death.

We can see just as much how much the (scholarly) written word is so willingly turned towards the past and the archives, the elsewhere or the abstract, and how important it is for the metis to be in the present - not to be caught out of time, to have a grip on time ${ }^{26}$ and to master the tempo to ensure the future:

Engaged in a world of becoming and confronted with situations which are ambiguous and unfamiliar and whose outcome always lies in the balance, wiley 
intelligence is only able to maintain its hold over beings and things thanks to its ability to look beyond the immediate present and forsee a greater or lesser section of the future [...]. During the struggle, the man of metis - compared to his opponent - displays at the same time a greater grip of the present where nothing escapes him, more awareness of the future, several aspects of which he has already manipulated [...]. He acts faster than lightning. This is not to say that he gives way to a sudden impulse [...]. On the contrary, his metis knows how to wait patiently for the calculated moment to arrive ${ }^{27}$ (Detienne \& Vernant, 1974, p. 21-22 and p. 32). with chalk, using words scribbled on the sly and consciously unfinished sentences. In practice, he disorients his compass. Everything is in place for the words to kill (him):

On March 1, this same Treviranus received an impressive-looking sealed envelope [...]; it contained a letter signed "Baruch Spinoza" and a detailed map of the city, clearly torn out of a Baedeker. The letter predicted that on the third of March there would not be a fourth crime [...]. [...] "the perfect points of a mystical, equilateral triangle"; red ink on the map demonstrated its regularity. Treviranus [...] sent both letter and map [...]. Erik Lönnrot studied the map and letter [...]. Lönnrot sensed, abruptly, that he was on the brink of solving the riddle [...]. For the last time, Lönnrot considered the problem of the symmetrical, periodic murders [...]. He [Scharlach] stepped back a few steps. Then, very carefully, he fired (Borges, 1974, p. 156-157 and 162-163).

\section{Narrative as a trap}

The conflicting coexistence of worlds and forms of knowledge (the commissioner's explanatory knowledge, the detective's interpretive knowledge and the criminal's practical knowledge) shapes the composite cultural poetics of the narrative. It manifests the heterodoxy of its metis through deceptive objects: "I have woven it [a labyrinth], and it has stood firm: its materials are a dead heresiologue, a compass, an eighteenth-century cult, a Greek word, a dagger, the rhombuses of a paint factory..." (ibid., p. 160).

This cultural heterophony is woven into the textuality of the narrative in a deliberately enigmatic way because "storytelling narrativity" is always somewhat connected to metis. ${ }^{28}$ If Borges' narrative tests readers on their own generic skills, as Baroni's detailed analysis suggests (2003, p. 141-157), the narrative plays on and no doubt thwarts them at first reading - a narrative anthropology cannot, however, ignore the agonistic logic of the cultural schemas that structure it. This is a crucial point when we know that metis is a mode of being/action that has become illegitimate - first and foremost in academic culture - and therefore is particularly doomed to go unnoticed as such in our cultures and readings ${ }^{29}$ This is not only because the modern state has a monopoly over legitimate violence (vigilante justice is not allowed), but also because modernity is written as the place of Logos par excellence - the ideal for silent and personal reflection, for ideational productions - (Furet \& Ozouf, 1977, p. 358-360), which is as different to the carnival "party horns bleating" (Borges, 1974, p. 154) as to the "suburb filled with factories" (ibid., p. 157) and brothels (ibid., p. 154) where the dominant culture is one of oral tradition and manual skills, ${ }^{30}$ control of a local community that takes care of its own, and time-honoured values that may run contrary to the rest of civilisation if necessary. ${ }^{31}$ Borges' story is like a return to this historical and sociological repression: this (metis) will kill that (the universe of the Logos). It is therefore the semantic and axiological coherence of the textual information that is at stake, and beyond this, the 
understanding of the culture of the text. We will provide a few examples of this metis in the story.

\section{Narrative trickery} explains his crimes, which culminate in the detective's murder), but it reveals above all that in a confrontational situation, cunning used for a cause has the power to ensure decisive domination over others. ${ }^{32}$ In fact, this undulating narrative profile is also a way to deconstruct the novel writing process through a mise en abyme: if the labyrinth is the representation of the trickery in which the detective is trapped (his murderer covers his tracks to better weave his web and tie up the loose ends of his plan; or like in Renard, feigns death to catch his prey), it is also the humorous and ambivalent manifestation of a plot twist. It is the linearity that comprises any written narrative that here becomes a pastiche, contested and re-semanticised.

\section{A semiography}

"For the last time, Lönnrot considered the problem of the symmetrical, periodic murders" (ibid., p. 162). The graphic lesson he sketches out - "[...] (or commit) one crime at $\mathrm{A}$, a second crime at $\mathrm{B}$, eight kilometers from $\mathrm{A}$, then a third crime at $\mathrm{C}$, four kilometers from A and B and halfway between them. Then wait for me at D [...]" (ibid., p. 162-163) - can be read/understood as a connection to the great critical tradition of 
Western novels to go against the grain of following narrative linearity. We already see this graphic outline in Sterne's Tristram Shandy (2004 ${ }^{33}$, p. 657), which simplifies the story's adventures.

By which it appears, that except at the curve, marked A. where I took a trip to Navarre,-and the indented curve B. which is the short airing when I was there [...], -I have not taken the least frisk of a digression, till John de la Casse's devils led me the round you see marked D.-[...], and the common ins and outs incident to the lives of the greatest ministers of state; and when compared with what men have done,-or with my own transgressions at the letters A B D-they vanish into nothing.

If this self-mocking map of written culture and this pleasing analytical diagram of a character's destiny find such an unexpected alphabetical echo, it is because they have both an interest and a purpose. In Borges (1978 ${ }^{34}$, p. 137-144), the semiographic attention paid to the formal elements of language are a constant of his sharp and witty modernity: "The line is made up of an infinite number of points; the plane of an infinite number of lines; the volume of an infinite number of planes; the hypervolume of an infinite number of volumes... No, unquestionably this is not - more geometrico - the best way of beginning my story. 35 "

This interest in the materiality of the book and the architecture of the page down to its basic components ${ }^{36}$ means that for the novelist the lines are not only semaphoric (they carry the written signs of language) but possibly semiophoric (they can be part of the semiotic process of meaning). This spatialisation, geometrisation and linearisation of the world on paper runs counter to the idea that the text is nothing more than "a mere labyrinth of letters" (Borges, 1974, p. 94), whereas the work of creating meaning in the narrative quite clearly renews the semantic potential of its typographic infrastructure. Indeed, it is on "a slip of paper" (ibid., p. 151) that the "rectangular prison" (ibid., p. 160) confining any prisoner - and any story - is written; it is on "one straight line [...] a single straight line (ibid., p. 162-163) that the labyrinth "that is invisible and incessant", in which one may get wonderfully lost, is ideally written in any detective story; and to show the height of the derision and foolishness of the written word, it is in and through the written word itself that this semiography is conveyed through the definitive silence of death which ends the narrative, the final point and eternal white light: "So many [...] have been lost upon that line [...]. Kill me at D [...]. He stepped back a few steps. Then, very carefully, he fired" (ibid., p. 163).

Thus, from narrative and meta-narrative intertext (Sterne) to Borgesian intra-text, the world of the straight line of writing and the (typo-)graphic order have an "expressive function" (McKenzie, 1991, p. 25-54) and contribute to the production of meaning - and the shedding of blood - here. ${ }^{37}$ This creation of meaning is thus consistent with the metis of the narrative which, between form and interpretation, links the written word to death.

\section{Subtext in brackets}

This hermeneutic play on the meaning of infra-linguistic forms can be found, for example, in the numerous brackets employed throughout the text. These brackets are used to play with the structural ambiguity of the punctuation - between providing background information and/or showing narrative confidence (Privat, 2016) - to better introduce what appears to be relatively trivial yet also important details ("it was 
carnival time, after all" or "supplemented by a tissue-thin false beard"), or to draw attention to the basic realism of the intelligence behind the facts: "That criminal (like so many others)" (Borges, 1974, p. 149). The reader must constantly deal with these enunciative ambiguities, which can appear innocent and thus suspiciously factual, such as with "Ginzberg (or Ginsburg)" (ibid., p. 153), or as strange, redundant warnings that are almost (overly) complicit with the presumed wisdom of the reader - "Erik Lönnrot smiled and in a grave voice read the commissioner a passage (which had been underlined)" (ibid., p. 155). Sometimes, entire sentences appear to be naïve diversions or awkward, intrusive delays (as a trompe l'oeil?) throughout the narrative: "(The singular manner of his death seemed fitting: Azevedo was the last representative of a generation of outlaws who used a knife but not a revolver.)" (ibid., p. 153). "To that tower (which was notorious for uniting it itself the abhorrent whiteness of a sanatorium, the numbered divisibility of a prison, and the general appearance of a house of ill repute) [...]" (ibid., p. 150). "(Thus testified the tetrarch's driver, who was sleeping in the adjoining room.)" (ibid.).

61 These literary devices are thus like metis pushbuttons in that, according to the textual conjunctures, they trigger undecidable interpretative conjectures, even upon rereading.

\section{A figure of the oblique}

The harlequin, a figure of verbal and moral pretence, is complicit with metis as an undulating and colourful intelligence that makes a profession of misdirection and getting out of any trap, somewhere between diabolism and shadow theatre: "A closed coupe had stopped in front of the tavern. The driver hadn't left the driver's seat; some of the customers recalled that he was wearing a bear mask. Two harlequin figures got out of the car [...]; and no one could fail to notice that they were drunk" (ibid., p. 154). "Gryphius [...] was in the middle, between the masked harlequins. (One of the women in the bar recalled the yellow, red, and green lozenges). Twice he stumbled; twice the harlequins steadied him [...]. The last harlequin scrawled an obscene figure and sentence on one of the blackboards in the entryway" (ibid., p. 155). "A stairway took him to the belvedere. The moonlight of the evening shone through the lozenges of the windows; they were yellow, red, and green. He was stopped by an astonished, dizzying recollection" (ibid., p. 159). "[...] the Name of God, YHVH, consists of four letters; the harlequins and the paint manufacturer's emblem suggest four terms [...]. It was I who sent the equilateral triangle [...]. I knew you would add the missing point, the point that fixes the place where a precise death awaits you" (ibid., p. 162). "He [Lönnrot] looked at the trees and the sky subdivided into murky red, green, and yellow rhombuses [...]. The night was dark now [...]. For the last time, Lönnrot considered the problem of the symmetrical, periodic murders [...]" (ibid.).

The harlequin is an oblique and composite figure par excellence, reflecting the linguistic ingenuity of the servants and the carnivalesque brilliance of turning the tables on the most uncertain situations. But here, the theme of the harlequin and masquerades is tied to "the twisting rue de Toulon, as they walked through the dawn's dead streamers and confetti [...] (ibid., p. 155) - in short, the "scene of the crime" and the "mask of blood" (ibid., p. 153):

The second crime took place on the night of January 3, in the emptiest and most godforsaken of the echoing suburbs on the western outskirts of the capital. 
Sometime around dawn, one of the mounted gendarmes [...] saw a man, wrapped in a poncho, lying in the doorway of an old paint factory. On the wall, across the red and yellow rhombuses, someone had chalked some words [...] (ibid.). (words from Spanish, French, German, Hebrew, Latin), performative speech ("sworn upon his honour") and gnomic speech ("no need to go off on wild-goose chases here", "all roads lead to Rome"), as well as the evocation of ancient magical and religious linguistic taboos ("the ineffable Name of God", "the magical fear of even numbers", "the reverent fear of speaking the Name of God", "the virtues and terrors of the Tetragrammaton" etc.). But it is around the idea of articulation that the semantic and interpretative issues are focused. of course, "to articulate" something can apply to when Yarmolinsky or another journalist writes an article, when a cabbalist "composes" the Name of God (Rabi, 1981, p. 273-286) or when a way of speaking (guttural, falsetto, raspy, etc.) hinders or distorts communication. But in the written and repeated occurrences of the word "articulada" ("written" in the English translation), there is both an insistence and an equivocation about the writing of a letter: Should it be considered together with other elements or separate? Read silently or said aloud? Does it transgress a religious taboo or reveal a criminal truth? It is obviously up to the reader to decide, just as one might imagine that "Death and the Compass" could be a fictionalisation of idioms such as "falling into one's own trap", "putting oneself in harm's way", "be on the road to ruin"39, "stare death in the face", "plot one's revenge", "get knocked off course".

67

is another way of understanding articulation if we take the crime-story intertext and imaginary world of the narrative into account. In one of Poe's most famous 
Extraordinary Tales, the hero is in articulo mortis and the whole story revolves around this extreme situation (Poe, 1869b, p. 379). However, if being at the point of death literally means being between life and death, this was exactly the case for Scharlach's brother and for Scharlach himself. ${ }^{40}$ In a sense, this is also the case throughout the story for Lönnrot. Thus, we might say that the story crystallises around the term articulada and that this word is about the interpretative work itself. The reader must in fact combine both the dispositions of the literate habitus (the reader is also a solitary, silent, immobile, speculative actor, etc.) and the cunning intelligence of metis, always in touch with the hic et nunc of events and the kairós of in vivo interactions (such as in oral storytelling ${ }^{41}$ ).

The reader must be wiser and more "insightful" (Borges, 1974, p. 156) than the "man in the street" (ibid., p. 162). Ever alert, the reader must rise to the level of the metis of the character and the writer (the decoy and the agent of the decoy are one here) who leaves "clues" so as to inspire inductions that are as reasonable as they are erroneous. We are touching on the limits of the epistemological and epistemophilic vulgate of ordinary discourse, which tends to oppose reason and imagination, cunning and thought, chance and necessity, myth and philosophy, or reflexivity and pragmatism. Thus, we could set the limits of a brilliant narratology ${ }^{42}$ which, with a more or less assumed deficit of anthropology, would confine itself to opposing pathos and logos, or even pathos, logos and mythos. ${ }^{43} \mathrm{~A}$ more relevant hermeneutic code seems to be the form of a rhombus whose diagonal lines would create a discursive and cultural dialogue among pathos/logos/mythos/metis.

I will leave my critical and wily readers here to their "hospitable imagination" (Borges, 1978, p. 147) in further pursuit the idea of cultural hermeneutics of literature and belief systems.

\section{BIBLIOGRAPHY}

BARONI, R. (2003). « Genres littéraires et orientation de la lecture. Une lecture modèle de "La mort et la boussole" de J. L. Borges ». Poétique 134, p. 141-157. En ligne : https://www.cairn.info/revuepoetique-2003-2-page-141.htm.

BARONI, R. (2007). La Tension narrative. Suspense, curiosité et surprise. Paris : Éditions du Seuil.

BARONI, R. (2009), « Passion de l'horreur et raison de l'enquête face à la "catastrophe ultraviolette" ». A contrario 11, p. 43-61. En ligne : https://www.cairn.info/revue-acontrario-2009-1-page-43.htm.

BORGES, J. L. (1974) [1942]. « La mort et la boussole ». Trad. de l'espagnol par P. Verdevoye. In : Fictions. Paris : Gallimard, p. 149-163.

BORGES, J. L. (1978). Le Livre de sable. Trad. de l'espagnol par F. Rosset. Paris : Gallimard. BORGES, J. L. (1980) [1970]. « Essai d'autobiographie ». Trad. de l'anglais par M. Seymour Tripier. In : Livre des préfaces suivi de Essai d'autobiographie. Paris : Gallimard. 
BORGES, J. L. (1986) [1932]. Discussion. Trad. de l'espagnol par C. Pailler-Staub. Paris : Gallimard. BORGES, J. L. (1994) [1944]. Fiction/Ficciones. Trad. de l'espagnol par R. Caillois, N. Ibarra et P. Verdevoye. Paris : Gallimard.

BOURDIEU, P. (1994). Raisons pratiques. Sur la théorie de l'action. Paris : Éditions du Seuil. BOURDIEU, P. (1997). Méditations pascaliennes. Paris : Éditions du Seuil. BOURDIEU, P. (2000) [1972]. Esquisse d'une théorie de la pratique, précédé de Trois études d'ethnologie kabyle, Paris : Éditions du Seuil.

CASSAR, C. (2005). L'Honneur et la honte en Méditerranée. Trad. de l'anglais par A.-M. Lapillonne. Aixen-Provence : Édisud.

CERTEAU, M. (1980). L'Invention du quotidien, t. 1. Arts de faire. Paris : Union générale d'éditions.

DETIENNE, M. \& VERNANT, J.-P. (1974). Les Ruses de l'intelligence. La mètis des grecs. Paris : Flammarion. EISENZWEIG, U. (1983). Autopsies du roman policier. Paris : Union générale d'éditions, p. 289-304.

FREUD, S. (2001) [1919]. L'Inquiétante étrangeté et autres textes. Trad. de l'allemand par F. Cambon. Paris : Gallimard, p. 25-149.

FURET, F. \& OZOUF J. (1977). Lire et écrire. T. 1. L'alphabétisation des français de Calvin à Jules Ferry. Paris : Éditions de Minuit.

GOODY, J. (1968). Literacy in Traditional Societies. Cambridge : Cambridge University Press, p. 1-26. GOODY, J. (1979). La Raison graphique. La domestication de la pensée sauvage. trad. de l'anglais par J. Bazin et A. Bensa. Paris : Éditions de Minuit.

GOODY, J. (2006). « La technologie de l'intellect ». Trad. de l'anglais par J.-C. Lejosne.

Pratiques 131-132, p. 7-30. En ligne : https://www.persee.fr/doc/

prati_0338-2389_2006_num_131_1_2114.

GUTWIRTH, J. (1970). Vie juive traditionnelle. Ethnologie d'une communauté hassidique. Paris : Éditions de Minuit.

HARTOG, F. (1977). « Une archéologie de la mètis ». Annales. Économise. Sociétés. Civilisations 32, p. 49-53. En ligne : https://www.persee.fr/doc/ahess_0395-2649_1977_num_32_1_293796.

MARIN, L. (1978). Le Récit est un piège. Paris : Éditions de Minuit.

MCKENZIE, D. F. (1991). La Bibliographie et la sociologie des textes. Trad. de l'anglais par M. Amfreville. Paris : Éditions du Cercle de la Librairie.

PITT-RIVERS, J. (1997) [1977]. Anthropologie de l'honneur. La mésaventure de Sichem. Trad. de l'anglais par J. Mer. Paris : Hachette.

POE, E. A. (1869a) [1841]. « Double assassinat dans la rue Morgue ». Histoires extraordinaires. Trad. de Ch. Baudelaire. Paris : Michel Lévy frères, p. 33-91.

POE, E. A. (1869b) [1845]. « La vérité sur le cas de M. Valdemar ». Histoires extraordinaires. Paris : Michel Lévy, p. 337-352.

PouILLOUX, J.-Y. (1992). Fictions de Jorge Luis Borges. Paris : Gallimard.

PRIVAT, J.-M. (2006). « Un habitus littératien?». Pratiques 131-132, p. 125-130. En ligne : https:// www.persee.fr/doc/prati_0338-2389_2006_num_131_1_2122. 
PRIVAT, J.-M. (2014). « La cabriole digressive du hobby horse ». Colloque Imaginaire contemporain, Université du Québec à Montréal, 23 avr. En ligne : http://oic.uqam.ca/fr/communications/lacabriole-digressive-du-hobby-horse.

PRIVAT, J.-M. (2016). « (Et il la regardait.) Un destin entre parenthèses ». Flaubert 16. En ligne : http://flaubert.revues.org/2594.

PRIVAT, J.-M. (2017). « Le bon pasteur républicain. Un transfert de sacralité ». Implications philosophiques, 5 juil. En ligne : http://www.implications-philosophiques.org/actualite/une/lebon-pasteur-republicain-un-transfert-de-sacralite.

PRIVAT, J.-M. (2018a). « Le cadavre du réalisme ». Cahier ReMix 7. En ligne : http://oic.uqam.ca/fr/ remix/le-cadavre-du-realisme.

PRIVAT, J.-M. (2018b). « La fortune des Chats ». Les Cahiers naturalistes 92, p. 33-48.

RABI, (1981). «Fascination de la Kabbale ». In : Roux, D. de et Milleret, J. de (dirs), Jorge Luis Borges. Paris : Éditions de L’Herne, p. 273-286.

ScHWinT, D. (2005). « La routine dans le travail de l'artisan ». Ethnologie française 35, p. 521-529. En ligne : https://www.cairn.info/revue-ethnologie-francaise-2005-3-page-521.htm.

SIMMEL, G. (1999) [1908]. Sociologie. Étude sur les formes de la socialisation. Trad. de l'allemand par L. Deroche-Gurcel et S. Muller. Paris : Presses universitaires de France.

SPINOZA, B. (1965) [1670]. Traité théologico-politique. Trad. par C. Appuhn. Paris : Flammarion.

SPINOZA, B. (2011). Éthique. Trad. de R. Misrahi. Paris : Hachette.

STERNE, L. (2004) [1759-1767]. La Vie et les opinions de Tristram Shandy. Trad. de l'anglais par G. Jouvet. Auch : Tristram.

TODOROV, T. (1971) [1966]. Poétique de la prose. Paris : Éditions du Seuil.

VERNANT, J.-P. (1989). L'Individu, la mort, l'amour. Soi-même et l'autre en Grèce ancienne. Paris : Gallimard.

\section{NOTES}

1. The English citations have been quoted from Borges, J.L. (1998) [1942]. Collected Fictions. Translated by Andrew Hurley, Penguin Group (USA) Inc., New York, 1998.

2. For an introduction to the short story collection, see Pouilloux, 1992, especially pages $116-130$ on crime fiction.

3. Each of the descriptive details regarding the Villa Triste-Le-Roy - while overlooking the etymology of the name itself, the Latin and Ovidian tristis, which means mournful should be analysed, like this strange vision of a "round yellow moon" that defined in the garden, itself dreary, "two leaf-clogged fountains" (ibid., p. 158).

4. It is Borges himself (1980, p. 317-18) who refers to the short stories that make up the collection in its two parts - "The Garden of Forking Paths" and "Artifices" - as stories and even detective stories (Eisenzweig, 1983, p. 289-304).

5. The last word of the story's first sentence is eucalyptus, which literally means "well wrapped, covered, hidden". This scholarly designation refers to the way eucalyptus flowers remain hidden within an operculum until they bloom... just like our story. 
6. See, for example, Bourdieu (2000, p. 19-60 and notes p. 187-193); Pitt-Rivers (1997) and Cassar (2005). See also Simmel (1999, p. 431-433 and 525-529).

7. One need only reread, for example, Maupassant, "Une vendetta" (A Vendetta), 1883 ["she had sworn over his body"].

8. The concept of honour persists, if not in our ordinary morals, at least in our everyday language: legion of honour, do something in honour of, guests of honour, swearing on one's honour, the honour of France, the Staircase of Honour, upon one's honour, do the honours, pay honour to, honour to whom honour is due, all is lost save honour.

9. The original text (Borges, 1994, p. 262) refers to "hechos de sangre".

10. See the matrix study by Vernant (1989, p. 41-79). For contemporary examples, see also Privat (2017; 2018a; 2018b).

11. This death and this wrong dead person have all the characteristics of a bad death (vs. a good death and the right dead person): unjust, violent, solitary, sudden, premature, inhumane and deprived of any funeral rite (Yarmolinsky did die but was never buried in the story). The text is almost curiously realistic about this insulted corpse: "He [Yarmolinsky] was found lying on the floor of his room, his face by now slightly discolored, his body almost naked beneath an anachronistic cape. He was lying not far from the door to the hallway; a deep knife wound had rent his chest" (ibid., p. 150). The wrongly murdered man triggers the summary execution of the drunken criminal and de facto sets in motion the rest of the story. He haunts the text. The presence of the dead man (his library, his language, his beliefs, the history of his people etc.) is virtually inseparable with the rabbi's "sacrifice". The tragic and necessary circumstances of his murder return, since the narrative (and therefore anthropological) configuration of the story is based both on the duality of hypotheses "I realized that you would conjecture that the Hasidim had sacrificed the rabbi" (ibid., p. 161) - and on the narrative repetition of scenarios - "Azevedo stabbed him once in the chest" (ibid., p. 150).

12. The same applies to the elimination - almost "ritualistic" in a way - of Azevedo by his "unlucky murderer" (ibid., p. 149).

13. Borges directly mentions or alludes to the Bible and the work of Spinoza, Poe and Joyce, as well as many scholars and obscure authors.

14. Lönnrot's Logos is fascinated by the symmetrical and specular configurations of criminal time and space, symmetrical devices and mirror reflections that the narrator qualifies as "pointless" (Borges, 1974, p. 158).

15. For more information about the Hasidim, see Gutwirth (1970).

16. At the beginning of the story, the narrator foretells this end with a troubling and vague prolepsis: "It is true that Erik Lönnrot did not succeed in preventing the last crime, but he did, indisputably, foresee it. Nor did he divine the identity of Yarmolinsky's unlucky murderer, but he did perceive the evil series' secret shape and the part played in it by Red Scharlach [...]" (Borges, 1974, p. 149).

17. For more about August Dupin, who was happy with "just books" and who ends up solving a crime when police were unable to, see Poe (1869a).

18. ${ }^{17}$... in a pastiche of the ending of "The Murders in the Rue Morgue" (Poe, 1869a). 
19. The English citations have been quoted from Detienne, M. \& Vernat, J.-P. (1978) [1974]. Cunning Intelligence in Greek Culture and Society. Translated from the French by Janet Lloyd, The University of Chicago Press, Chicago and London.

20. See also Vernant's interview with Charbonnier at http://www.fabriquedesens.net/ Les-ruses-de-l-intelligence-La.

21. We have referred to the mythological origins of Metis - the goddess whom Zeus married and then swallowed - in Privat (2018b). "The Combats of Zeus" and "The Union with Metis and the Sovereignty of the Sky", p. 61-103 and p. 104-125.

22. While the traitor Azevedo is impulsive (Borges, 1974, p. 161), Scharlach is a master of self-control and coldly executes his plan.

23. See Pierre Bourdieu, "Le point de vue scolastic" ("The Scholastic Point of View", 1994, p. 213-230) and especially "Le point d'honneur scolastique" ("The Scholastic Point of Honour", 1997, p. 36-39).

24. "The driver hadn't left the driver's seat; some of the customers recalled that he was wearing a bear mask [...]. Two harlequin figures [...] burst into Finnegan's office, party horns bleating [...]. Gryphius [...] supplemented by a tissue-thin false beard [...] Tall and unsteady, he was in the middle, between the masked harlequins [...]. 'What if tonight's story were a sham, a simulacrum?"' (Borges, 1974, p. 154-155 and 161).

25. The pseudonym Gryphius condenses the character's different facets, where the name refers to a famous Renaissance printer-bookseller from Lyon or a German baroque poet and connotes an animal's claw as the signature of the writer. We know how proud Borges was of his own hybrid culture, between the reality of the scholar and his more or less imaginary connection to the world of the gaucho on the Pampas.

26. The text creates a theme around the role of cyclical time and the manipulation of the calendar from an angle that is either poetic or dramatic - "three years ago", "one dawn and one sunset", "those deserted evenings that have the look of dawn", "I chose the third of January", "symmetry in time", "the deaths occurred on the fourth of each month" - but also historical or cultural - "the Jewish day begins at sundown", "Jews compute the day from sunset to sunset", "le 3 sera le 4".

27. For more on metis as a "practice of time" and especially the kairos (the opportune moment), see Certeau (1980, p. 153-167).

28. De Certeau, 1980, p. 156 and Marin, 1978. See also the novel as a "game of attention, echoes and affinities", "the long repercussion of words" and the "shadowy exactness" of any "polished" story (Borges, 1986, p. 90-100).

29. Philosophical thought and religious thought, but also political thought, legal thought and patriarchal thought are each wary in their own way of cunning behaviour, hybrid imaginations, the resourcefulness of the weak, customary codes and the power of affects, all deviant and undulating, lateral and oblique approaches that metis values (Ulysses, Circe, Renard).

30. See Detienne \& Vernant (1974) "The Fox and the Octopus", p. 32-57 and in various passages on the hunter, the warrior, the craftsman; see also Schwint (2005).

31. Outlaws live on the fringes of society, the city and its values. The "distant scene of the crime" (the execution of Azevedo), for example, is in "the emptiest and most godforsaken of the echoing suburbs on the western outskirts of the capital" (Borges, 1974, p. 152-153), right where "the city crumbled away" (ibid., p. 153); and when 
Lönnrot goes towards the "abandoned Villa Triste-le-Roy", "he saw dogs, he saw a van or lorry in a dead-end alleyway" [...]" (Ibid, p. 157-158). The economic stakes (the theft of the sapphires) do not preclude the symbolic stakes (the honour code) and the use of cunning intelligence to ensure bloody vengeance is extracted (blood ties). Any offence is a challenge and honour is an undivided good that can be lost. See Bourdieu, 2000, p. 30, p. 37 and p. 190.

32. The commissioner "guessed" that the crime was a simulacrum (Borges, 1974, p. 161) because that was the only logical conclusion, and he knew that for Lönnrot, "there was something of the adventurer in him, even something of the gambler" (ibid., p. 149), to the point that he loses out on any possible benefit to his reasoning ability and leaves himself exposed.

33. The English citations have been quoted from Sterne, L. Tristam Shandy: Chapter 3.LXXXIII. Sparknotes.com. Retrieved 17/12/2020 from https://www.sparknotes.com/ lit/tristram/full-text/chapter-3lxxxiii/.

34. The English citations have been quoted from Borges, J.L. (1977) [1975]. The Book of Sand. Translated by Norman Thomas Di Giovanni, E.P. Dutton, New York.

35. The rest of this text sometimes directly echoes passages from "Death and the Compass": "I acquired the book in a town out on the plain in exchange for a handful of rupees and a Bible. Its owner did not know how to read. I suspect that he saw the Book of Books as a talisman", just as other passages do in "The Library of Babel" (Borges, 1974, p. 94): "I know of one semibarbarous zone whose librarians repudiate the "vain and superstitious habit' of trying to find sense in books, equating such a quest with attempting to find meaning in dreams or in the chaotic lines of the palm of one's hand..."

36. There are many more examples: “[...], each book contains four hundred ten pages; each page, forty lines; each line, approximately eighty black letters [...]. [...] all books [...] consist of identical elements: the space, the period, the comma, and the twenty-two letters of the alphabet" (Borges, 1974, p. 95). For an ethnocritical approach to the role of the line in literature, see Privat, 2014.

37. Lönnrot's plan has the fatal flaw of turning time into space ("Then wait for me at D, two kilometers from A"), and in doing so ignores the spacing of time, unlike Scharlach's metis, which plays with this manipulation as we have seen.

38. Scharlach's own account will take up these formulas point by point.

39. It would be easy to follow Lönnrot's path from life to death according to the ritual sequence of separation (from the civilised urban world) and being in the margins, which already represent a societal and symbolic death (a remote, unknown, secret, nocturnal, moonlit, solitary, silent, strange place strewn with physical obstacles and ontological enigmas such as the "pointless cry of a bird").

40. An anthropological analysis can obviously interpret Lönnrot's bad death (solitary, sudden, violent, premature, unjust etc.) as an imaginary form of ritual transaction with the bad death of the brother (whose first name is never given), where Scharlach is like a doppelgänger of the dead man and in this sense is the dead man himself come back to life. He acts in some way in place of the dead man, including in the system of factual homologies that links the two brothers in textual death: the gambling den in the rue de Toulon, for example, is linked to Liverpool House where Scharlach-Ginzberg-Gryphius was staying. This is where the commissioner conducts part of his investigation and 
Lönnrot treads on the "dead streamers" of the dawn. Treviranus receives an apparently decisive letter from Scharlach, which mentions the rue de Toulon and the tavern and "little room" where he was staying and where - as the killer recalls "three years ago [...] you arrested my brother and saw that he was sent to prison". The prison where his brother lay dying is a "symmetrical" situation to the desolate villa where Scharlach would later end up for nine days, feverish and delirious, hungry for revenge.

41. "There was a turning point in Greek culture [...], roughly at the end of the fifth century, beginning of the sixth century, when a culture that was fundamentally oral [...], that moment when with writing, with mathematics, new forms of thought were invented [...], a clear opposition between [...] the sensitive world of that is unfurling in which we live and with which we are confronted [...] and another, completely different world which is [...] the world of identity, permanence, constancy" (Charbonnier \& Vernant: http://www.fabriquedesens.net/Les-ruses-de-l-intelligence-La).

42. Our analyses thus diverge only partially (chance or random vs. metis, here in any case) from those of Baroni (2009) when he says that the best detective stories (Poe, Collins, Doyle, Borges) are "woven from the delayed adequacy of thought to the world", "The passion of horror and the reason for investigation [...]".

43. Borges' story ostentatiously includes the names of mythological characters such as Janus, Diana and Hermes.

\section{ABSTRACTS}

The short story by Jorge Luis Borges, "Death and the Compass" (Collected Fictions, 1942), stages the life and death struggle between a detective - "a reasoning machine" - modelled on classic detective stories and a killer who follows the rigid rule of societies bound by a strict honour code (brotherhood, blood vengeance, death). The aim of our ethnocritical study is to show how two contradictory worlds (that of writing and literacy and that of folk knowledge) fatally collide through the cunning intelligence of an honour-bound criminal who is a master in the art of cultural syncretism [metis]. Our approach is different to those based on the formal rules of narratology. By examining several examples of cultural and narrative heterophony, we can show how a traditional literary analysis hinders an anthropological interpretation of the story and its structure, as well as the values and beliefs it reflects.

La nouvelle de J. L. Borges - «La mort et la boussole » (Fictions, 1942) - met en conflit mortel un détective inscrit dans la filiation du roman policier classique - "un pur raisonneur » - et un tueur qui obéit - entre autres - à la loi implacable des petites sociétés à honneur (la fratrie, le sang, les morts). Notre étude ethnocritique vise à montrer comment une affiliation à des cosmologies contradictoires (monde de la raison graphique/monde de la pensée sauvage) trouve sa résolution fatale dans l'intelligence rusée du bandit d'honneur maitre en mètis. Notre lecture s'éloigne donc des lectures marquées d'un certain formalisme narratologique. L'analyse de quelques cas concrets d'hétérophonie culturelle et narrative permet de pointer en quelle façon une herméneutique lettrée traditionnelle fait obstacle à une interprétation anthropologique du récit, son architecture, ses valeurs, ses croyances. 
INDEX

Keywords: ethnocriticism, Borges (Jorge Luis), detective story, literacy and writing, honour codes, cultural syncretism [metis], cunning writing

Mots-clés: ethnocritique, Borges (Jorge Luis), conte policier, raison graphique, culture de l'honneur, mètis, écriture rusée

\section{AUTHORS}

JEAN-MARIE PRIVAT

University of Lorraine, CREM, F-57000 Metz, France 